\title{
Modified fine-grained concrete for facing and repair of the hydraulic structures
}

\author{
Yuri Bazhenov ${ }^{1}$, Boris Bulgakov ${ }^{1, *}$, and Olga Alexandrova ${ }^{1}$ \\ ${ }^{1}$ Moscow State University of Civil Engineering, Department Technology of Binders and Concretes, \\ 129337, Russian Federation
}

\begin{abstract}
This article is devoted to improve the performance characteristics of plasticized fine-grained concrete for the hydraulic structures. The results of experimental studies on the selection of the optimal dosage of components. Justified the application of plasticized fine hydraulic concrete for facing and repair of the hydraulic structures. The result of the experimental study is the selection of the optimal composition of the fine hydraulic concrete with improved characteristics.
\end{abstract}

The Russian Federation has a large number of rivers with a total length of about 10 million $\mathrm{km}$, many of which are navigable. A large part of the river hydraulic structures due to their intensive use is in poor condition. Repair of such structures are generally very timeconsuming and expensive.

To solve the problem of increasing the effective performance of hydraulic fine-grained concretes need to optimize their composition and technology of preparation and use the organic and mineral modifying additives [1-5].

The aim of the work was to obtain the fine-grained concrete for facing and repair of river hydraulic structures which has the necessary strength, waterproofness and frost resistance due to seal its structure through the use of the organic and mineral additives in the form of superplasticizer, metakaolin and hydrophobizing silicone fluid.

Table 1. Physical and mechanical properties of fine-grained concrete plasticized "Khimkom F-1".

\begin{tabular}{|c|c|c|c|c|}
\hline \multirow{2}{*}{ Composition and properties } & \multicolumn{4}{|c|}{ Number of composition } \\
\hline & $\mathbf{I}$ & II & III & IV \\
\hline Cement, kg & 550 & 550 & 550 & 550 \\
\hline Sand, kg & 1500 & 1500 & 1500 & 1500 \\
\hline "Khimkom F-1", kg & $11 \quad(0.6 \%)$ & $16 \quad(0.9 \%)$ & $\begin{array}{c}22 \\
(1.2 \%)\end{array}$ & $28(1.5 \%)$ \\
\hline Water, kg & 180 & 156 & 150 & 144 \\
\hline $\begin{array}{l}\text { Flow of fresh concrete (by the Flow table } \\
\text { test), mm }\end{array}$ & 160 & 115 & 150 & 159 \\
\hline Tensile strength at bending, $\mathrm{MPa}$ & 5.13 & 7.5 & 8.8 & 8.3 \\
\hline Compression strength, MPa & 26.4 & 46.2 & 55.4 & 53.2 \\
\hline
\end{tabular}

* Corresponding author: fakultetst@,mail.ru 


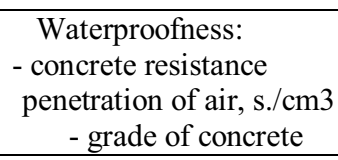

Note: in parentheses indicate the concentration of "Khimkom F-1" in \% by weight of cement in terms of dry matter.

To reduce the water demand of fine-grained sand-cement concrete mixture, while maintaining its desired mobility (the flow of fresh concrete by the Flow table test must be equal 150-160 mm) should be used superplasticizer [6-11]. As the plasticizer used superplasticizer "Khimkom F-1" as a 30\% aqueous solution (table 1).

Superplasticizer "Khimkom F-1" represents sulfonated product of the aldol condensation of formaldehyde. Superplasticizer concentration ranged from 0.6 to $1.5 \%$ of the cement mass in terms of dry matter additive.

Selecting "Khimkom F-1" as a superplasticizer due to the fact that the use of this plasticizer allow to obtain from highly mobile concrete mix, characterized by high uniformity, necessary persistence of mobility and practically requires not vibration compaction, strong and durable fine-grained concrete with a high frost resistance and waterproofness.

As a result of experimentation, it was found that the maximum compressive strength of the fine-grained concrete $(55.4 \mathrm{MPa})$ and its tensile strength at bending $(8.8 \mathrm{MPa})$ at 28 days of normal hardening, as well as its high waterproofness (W20) obtained by using superplasticizer "Khimkom F-1" in an amount of $1.2 \%$ of the cement mass in terms of dry matter (table 1).

One of the main factors softening concrete is its increased porosity [6]. It arises from the concrete degradation during operation, and is expressed in loosening its structure, weakening the connection between the crystal growths in the cement stone and cement stone and the particle aggregates, resulting in reduced strength of the concrete, and also promotes filtration of water and aggressive fluids at concrete volume and, in addition, abrasive and frosty destruction of concrete. The solution to this problem may be a significant seal structure of concrete.

Table 2. Determining the optimal content of metakaolin in strength and waterproofness of plasticized fine-grained concrete.

\begin{tabular}{|c|c|c|c|c|}
\hline \multirow{2}{*}{$\begin{array}{l}\text { Composition and } \\
\text { properties }\end{array}$} & \multicolumn{4}{|c|}{ Number of composition } \\
\hline & I (control) & II & III & IV \\
\hline Cement, kg & 550 & 550 & 550 & 550 \\
\hline Sand, kg & 1500 & 1472 & 1445 & 1417.5 \\
\hline "Khimkom F-1", kg & $22(1.2 \%)$ & $22(1.2 \%)$ & $22(1.2 \%)$ & $22(1.2 \%)$ \\
\hline Water, kg & 150 & 150 & 150 & 150 \\
\hline Metakaolin, kg & - & $27.5(5 \%)$ & $55(10 \%)$ & $82.5(15 \%)$ \\
\hline $\begin{array}{l}\text { Waterproofness: } \\
\text { - concrete resistance } \\
\text { penetration of air, s./cm3 } \\
\text { - grade of concrete }\end{array}$ & $\begin{array}{l}355.0 \\
\text { W20 }\end{array}$ & $\begin{array}{l}325.5 \\
\text { W20 }\end{array}$ & $\begin{array}{l}318.4 \\
\text { W20 }\end{array}$ & $\begin{array}{l}324.8 \\
\text { W20 }\end{array}$ \\
\hline $\begin{array}{c}\text { Tensile strength at bending, } \\
\text { MPa }\end{array}$ & 8.8 & 8.6 & 9.0 & 9.8 \\
\hline Compressive strength, $\mathrm{MPa}$ & 55.4 & 55.2 & 56.2 & 56.7 \\
\hline
\end{tabular}


Note: in parentheses indicate the concentration of additives in $\%$ by weight of cement.

To reduce the consumption of cement and seal of the concrete structure as a finely dispersed mineral additives in concrete mixture was introduced metakaolin (table 2). Moreover, the amount should not exceed $15 \%$ by weight of cement, as it contains active silicon dioxide, and aluminum oxide in about equal proportions and therefore stronger than microsilica binds free calcium hydroxide, which reduces the alkalinity of the medium in the concrete and can cause corrosion of steel reinforcement [12]. Furthermore, the introduction of metakaolin as any other from fine fillers in more quantity increases water demand of the concrete mix due to its fineness and a large specific surface area values reaching $15 \mathrm{~m}^{2} / \mathrm{g}$ and above [15].

As a result of experiments, it was found that when injected into the plasticized finegrained concrete mixture of highly active metakaolin with a specific surface area value 15 $\mathrm{m}^{2} / \mathrm{g}$ in the amount up to $15 \%$ by weight of cement while reducing the proportion of sand was a slight increase in strength of concrete after 28 days of normal hardening when tested tensile strength at bending from 8.8 to $9.8 \mathrm{MPa}$ while a slight increase its compressive strength from 55.4 to $56.7 \mathrm{MPa}$. According to the experimental data obtained a waterproofness of the fine-grained concrete as a result of the metakaolin introduction changed little and remained at a level corresponding grade of concrete on waterproofness W20 (table 2).

In order to improve a waterproofness and a frost resistance of a hydraulic fine concrete in the concrete mix was introduced a hydrophobizing silicone fluid [9]: "SOFEKSIL-40" which is a $50 \%$ aqueous potassium methylsiliconate concentrate.

As a result, it has been experimentally shown that the introduction of plasticized finegrained concrete mix "SOFEKSIL-40" in the amount of $0.2 \%$ of the cement mass effectively increases frost resistance and waterproofness of concrete. When using $0.2 \%$ "SOFEKSIL-40" actual concrete frost resistance increased from 492 to 653 test cycles, which corresponds to an increase in its mark on frost resistance from F400 to F600 (table 3).

Table 3. Determination of strength, frost resistance and waterproofness of plasticized fine-grained concrete hydrophobized silicone fluid.

\begin{tabular}{|c|c|c|c|}
\hline \multirow{2}{*}{ Composition and properties } & \multicolumn{3}{|c|}{ Number of composition } \\
\cline { 2 - 4 } & I (control) & II & III \\
\hline Cement, $\mathrm{kg}$ & 550 & 550 & 550 \\
\hline Sand, $\mathrm{kg}$ & 1500 & 1417.5 & 1417.5 \\
\hline "Khimkom F-1", kg & $22(1.2 \%)$ & $22(1.2 \%)$ & $22(1.2 \%)$ \\
\hline Water, kg & 150 & 150 & 150 \\
\hline Metakaolin, $\mathrm{kg}$ & - & $82.5(15 \%)$ & $82.5(15 \%)$ \\
\hline $\begin{array}{c}\text { CompressiL-40", kg } \\
\text { MPa }\end{array}$ & - & - & $1.1(0.2 \%)$ \\
\hline $\begin{array}{c}\text { Actual resistance to frost, } \\
\text { (test cycles) }\end{array}$ & 55.4 & 56.7 & 57.5 \\
\hline $\begin{array}{c}\text { Grade of concrete on frost } \\
\text { resistance }\end{array}$ & 492 & 446 & 653 \\
\hline \multicolumn{2}{c}{$\mathrm{F} 400$} & $\mathrm{~F} 400$ & $\mathrm{~F} 600$ \\
\hline
\end{tabular}




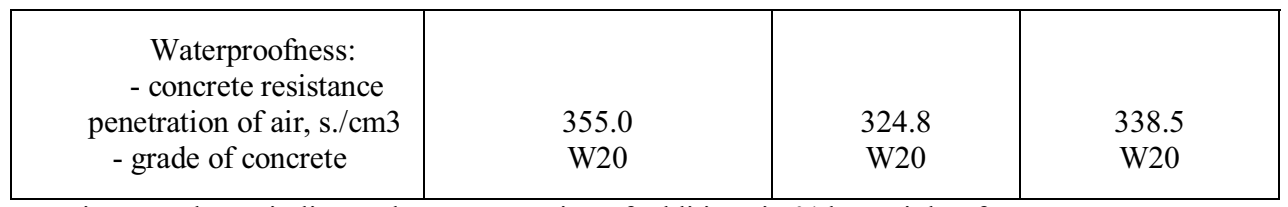

Note: in parentheses indicate the concentration of additives in \% by weight of cement.

Since the modified fine-grained concrete is designed for facing and repair of the hydraulic structures, and it should be laid in thin layers with a thickness of $10-30 \mathrm{~mm}$, it is necessary to evaluate the shrinkage deformation. To estimate the shrinkage deformation was used the following compositions:

-control composition - the plasticized coarse-grained concrete (class of compressive strength B 40);

•composition №1 - the plasticized fine-grained concrete (class of compressive strength B 40);

-composition №4 - the plasticized fine-grained concrete with the addition of highly active metakaolin and hydrophobizing silicone fluid "SOFEKSIL-40"( class of compressive strength B 50).

The test results are shown in table 4.

Table 4. The results of determinations of shrinkage deformation of concrete.

\begin{tabular}{|c|c|c|c|c|c|c|}
\hline \multirow{2}{*}{$\begin{array}{c}\text { Harden } \\
\text { ing } \\
\text { term }\end{array}$} & \multicolumn{2}{|c|}{ Control composition } & \multicolumn{2}{|c|}{ Composition №1 } & \multicolumn{2}{|c|}{ Composition №4 } \\
\hline & $\begin{array}{c}\text { Absolute } \\
\text { shrinkage } \\
\text {, mm }\end{array}$ & $\begin{array}{c}\text { Relative } \\
\text { shrinkage, } \\
\%\end{array}$ & $\begin{array}{c}\text { Absolute } \\
\text { shrinkage } \\
\text {, mm }\end{array}$ & $\begin{array}{c}\text { Relative } \\
\text { shrinkage, } \\
\%\end{array}$ & $\begin{array}{c}\text { Absolute } \\
\text { shrinkage, } \\
\text { mm }\end{array}$ & $\begin{array}{c}\text { Relative } \\
\text { shrinkage } \\
, \%\end{array}$ \\
\hline 1 & 0.122 & 0.08 & 0.106 & 0.07 & 0.066 & 0.04 \\
\hline 2 & 0.170 & 0.11 & 0.151 & 0.09 & 0.087 & 0.05 \\
\hline 3 & 0.199 & 0.12 & 0.175 & 0.11 & 0.096 & 0.06 \\
\hline 5 & 0.206 & 0.13 & 0.186 & 0.12 & 0.099 & 0.06 \\
\hline 7 & 0.206 & 0.13 & 0.181 & 0.11 & 0.099 & 0.06 \\
\hline 14 & 0.214 & 0.13 & 0.191 & 0.12 & 0.102 & 0.06 \\
\hline 28 & 0.214 & 0.13 & 0.202 & 0.13 & 0.102 & 0.06 \\
\hline
\end{tabular}

From the above test results shown that the samples of the developed fine-grained concrete are less prone to shrinkage than the control samples, what makes it possible to use the fine-grained concrete designed as a facing or repair material. Thus, the number and size of shrinkage cracks will be minimal.

Thus, in a result of conducted researches it was established that the introduction into the concrete mixture the organic and mineral additives in the form of superplasticizer "Khimkom F-1" (in the amount of $1.2 \%$ by weight of cement in terms of dry matter) with a strong plasticizing and water-reducing action, metakaolin (15\% by weight of the cement) as a fine mineral sealing component and hydrophobizing silicone fluid "SOFEKSIL-40" ( $0.2 \%$ by weight of cement) allows to obtain a hydraulic fine-grained concrete having high strength (compressive strength is equal $57.5 \mathrm{MPa}$ ), waterproofness (grade of concrete on waterproofness is W20) and frost resistance (grade of concrete on frost resistance is F600). In this case, the optimum ratio of raw materials in $1 \mathrm{~m}^{3}$ of the fine-grained concrete mixture is:

- cement - $550 \mathrm{~kg}$;

- sand - $1417.5 \mathrm{~kg}$;

- water - $150 \mathrm{~kg}$;

- "Khimkom F-1" (in terms of dry matter) - $6.6 \mathrm{~kg}$;

- metakaolin - $82.5 \mathrm{~kg}$;

- "SOFEKSIL-40" - $1.1 \mathrm{~kg}$. 


\section{References}

1. S. V. Aleksashin, B. I. Bulgakov, Collection of Research Papers of the Institute of Construction and Architecture (KYuG Publ., Moscow, 2012)

2. S. V. Aleksashin, B. I. Bulgakov, Vestnik MGSU 8, 97-103 (2013)

3. S. V. Aleksashin, B. I. Bulgakov, M. N. Popova, Izv. SFedU. Eng. Sci. 1, 195-201 (2014)

4. E. S. Ryibintseva, G. A. Tkachenko, Cons. Mat. 7, 18-20 (2009)

5. M. N. Moroz, V. I. Kalashnikov, V. A. Khudiakov, P. G. Vasil'ev, Cons. Mat. 8, 55-57 (2009)

6. Yu. M. Bazhenov, D. K.-S. Bataev, S.-A. Yu. Murtazaev, Energy and resource saving materials and technologies for repair and restoration of buildings and constructions (Komteh-Print Publ., Moscow, 2006)

7. Yu. M. Bazhenov, N. P. Lukutsova, E. G. Matveeva, Vestnik MGSU 4(2), 415-418 (2010)

8. S. P. Shah, S. H. Ahmad, High Performance Concrete: Properties and Applications (McGraw-Hill, Inc., 1994)

9. V. R. Falikman, et all, 6th Int. Cong. "GLOBAL CONSTRUCTION", Advances in Admixture Technology (Dundee, 2005)

10. N. P. Lukutsova, Cons. Mat. 9, 101-104 (2010)

11. N. P. Lukutsova, A. A. Pyikin, O. A. Chudakova, Vestnik BGTU im. V. G. Shukhova 2, 67-70 (2010)

12. V. S. Ramachandran, Concrete Admixtures Handbook Book. Properties, Science and Technology ( Elsevier Science Publ., 1996)

13. RILEM commission 42-CEA, Mater. Struct. 14(6), 399-450 (1981)

14. S. A. A. M. Fennis, Design of ecological concrete by particle packing optimization (TU Delft, 2011)

15. V. G. Batrakov, Modified Concretes. Theory and Practice (Tehnoproekt Publ., Moscow, 1998) 